\title{
Save the Children 9
}

NEEDS ASSESSMENT of WORKING CHILDREN in MAZAR-i-SHARIF 
NEEDS ASSESSMENT of WORKING CHILDREN in MAZAR-i-SHARIF

Cindy Dubble

August, 1997 


\section{Contents}

Page

Forward

Acknowledgements 4

Glossary 5

Executive Summary 6

Section 1 Introduction 9

Section 2 Methodology

Section 3

Findings of the Needs Assessment

Section 4

Case Studies of Working Children

Section 5

Attitudes and Perceptions about working children

Section 6

Recommendations

Appendices

I Save the Children's Position on Children and Work

II Survey Questionnaire

III Name List Formats

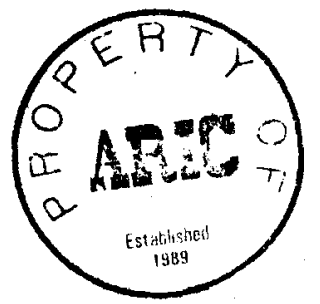




\section{Foreword}

For many years, SCF (UK) has been systematically engaged with working children's issues through both advocacy and project work throughout the world. SCF's position on children and work is based on the United Nations Convention on the Rights of the Child (CRC), experience and research in many parts of the world, and SCF's commitment to achieve lasting benefits for children. ${ }^{1}$

SCF (UK) has been working in Afghanistan and with Afghan refugees in Pakistan since 1980, primarily in the health and education sectors. In February, 1997, SCF established an office in Mazar-i-Sharif, in order to investigate the needs of the northern regions of Afghanistan. One of the immediate perceptions was that there were numerous working children in the city of Mazar-i-Sharif. As there was no previous research regarding the magnitude or specific needs of working children in Mazar, SCF decided to conduct a Needs Assessment of Working Children in Mazar-i-Sharif. The main objectives of this Needs Assessment are:

- To provide baseline date on the numbers of children working in Mazar-i-Sharif, the types of work they do, their family situation, and the degree of hazard and exploitation they face.

- To elicit the views of the children, their families, community members, and the local authorities regarding the reasons why children work, specific problems, and possible solutions.

- To recommend appropriate means of addressing the needs determined by the Needs Assessment

It is essential that all action involving working children is based on the reality of their lives, and is planned and developed with children, their families, and their communities. This Needs Assessment presents information and views obtained by observing and listening to working children, their families, and community members in Mazar. Their situation and views are unique, and specific to Mazar. The challenge is to develop responses which can meet the specific needs identified in this assessment.

Cindy Dubble

Consultant for SCF (UK), Afghanistan

August, 1997

${ }^{1}$ Refer to Appendix I for SCF (UK)'s Position on Children and Work 


\section{Acknowledgements}

\section{Thanks to:}

The working children in Mazar, their families, and community members who gave generously of their time, their hospitality , their trust, and their opinions.

The 17 surveyors, who survived long hours and the heat of Mazar to complete the Needs Assessment on time.

Engineer Yousuf (Director of the Aschiana Programme for children working in the streets in Kabul), for his willingness to share his expertise, his assistance in planning and implementing the Needs Assessment, and his inspiration.

Jamila Tellayee, (seconded by UNICEF) who assisted in all aspects of the Needs Assessment, facilitated the focus group discussions, and helped with translation.

The ACBAR Survey Unit (Peshawar, Pakistan) who completed all the data entry and analysis for the 300 questionnaires of working children and their families. Particular thanks to Mr. Abdul Hakim Murad, Survey Unit Manager, and Mr. Abdul Rahman, Computer Analyst, for their competency and good quality work.

Special thanks should be given to Shon Campbell, SCF (UK)'s Programme Manager for Afghanistan, who designed the project proposal and terms of reference for the Needs Assessment, secured funding, and facilitated logistics. She shared her knowledge and gave encouragement throughout the assessment process. All members of the SCF (UK) team in Mazar assisted in every way possible, and their support was much appreciated. The SC (US) team in Mazar also assisted in logistics, loaned the use of a computer, provided accommodation, and gave support.

The SCF (UK) team in Islamabad worked quietly and competently behind the scenes to assist with logistics and supplies. Special thanks to Samina Sardar, who assisted in monitoring the data entry and analysis.

Cindy Dubble, Consultant for SCF (UK) had overall responsibility for the Needs Assessment of Working Children in Mazar-i-Sharif. She designed the methodology, facilitated the training of surveyors, conducted the research, and wrote this report.

This Needs Assessment was funded by UNICEF and SCF (UK). 


\section{Glossary}

Terms used in this report:

Afs

Community Fora

boulani

pakora

ACBAR

ACTED

CRC

HABITAT

ICRC

NBSD

NGO

SCF (UK)

SC (US)

UNICEF
Afghanis, the Afghan currency

District Community Centres facilitated by HABITAT, providing meeting space, income generation, education, social services, youth group activities, and coordination of users groups for water and sanitation.

An Afghan snack

An Afghan snack
Agency Coordinating Body for Afghan Relief

Agency for Technical Cooperation and Development

The United Nations Convention on the Rights of the Child

United Nations Coordination for Human Settlement

International Committee of the Red Cross

National Bureau for Sustainable Development

Non-governmental Organisation

Save the Children Fund (United Kingdom)

Save the Children (United States)

United Nations Children's Fund

Exchange Rate used in this report: US $\$ 1=50,000$ Afghanis

(Note: This rate varies throughout Afghanistan, and from day to day) 


\section{Executive Summary}

This report summarizes the findings of a Needs Assessment of Working Children conducted in Mazar-i-Sharif in northern Afghanistan, during July and August, 1997. This assessment is intended as a reliable baseline on which SCF and other organisations can plan responses to the needs of working children in Mazar.

This research does not attempt to compare the needs of working children with the needs of other vulnerable groups of children in Mazar-Sharif. The Needs Assessment did not include children hidden from view, child domestic workers, or rural children. It focused on children between the ages of 5-14 who were working in Mazar city on the streets, in shops, and in factories.

Working children in Mazar-i-Sharif do not fit neatly into a northern definition of street child or child labourer. All the working children in Mazar have homes, and do not live on the street. Their work is not viewed as inappropriate labour in a country where traditional customs and beliefs prevail, and children are expected to work and contribute to the family's survival. Many families encourage their children to sell produce from home, learn a skill as apprentices in workshops, or work in a factory as a way of adding to the family's income. Within this cultural view, all such children were defined as working children.

\section{Key findings}

\section{Prevalence of working children:}

In total, $\mathbf{1 , 4 4 6}$ children were identified working in the streets, shops, and factories in Mazar-iSharif. Of these, $63 \%$ were working in the streets, and $37 \%$ were working in shops and factories. $94 \%$ of working children were boys, and $6 \%$ were girls. The majority of working boys are within the age group 1.1-14 (67\%), and the majority of girls are within the age group 8-10 (49\%).

\section{The main reason why children work is poverty.}

In $55 \%$ of the families interviewed, the child was the main source of income for the family. All the families were poor, with a monthly income well below Afs $6,000,000$, which is considered basic survival for families in Mazar. Children were able to earn between Afs 2,500 and Afs 50,000 per day, depending on the type of work. 


\section{Types of work}

The majority of boys were engaged in mechanical training/work (30\%) and selling water $(29 \%)$. Girls were primarily engaged in selling food from home $(40 \%)$ and collecting fuel items (34\%).

\section{Conditions of Work}

The work situations identified in this Needs Assessment did not expose the children to severe health hazards or serious exploitation. Although some of the children chose to work long hours on the streets and complained that the work was hard, the majority of children were able to rest during work, ate food, associated with friends, and were free to stop work if their families agreed. The main hazards for boys working in mechanic shops were lifting heavy engines, working with sharp, heavy tools, and contact with battery acid.

\section{The main disadvantage for working children in Mazar is the loss of educational opportunities.}

None of the children identified in this Needs Assessment are currently attending school. This is due to the necessity for these children to provide an income for their families, and the prohibitive cost of government schools. Many people in Mazar believe that the quality of education in government schools is so low that it is better for children to work and learn a skill than to attend school.

\section{6. $49 \%$ of the families interviewed had been displaced and $12 \%$ were returned refugees.}

Displacement is a major factor contributing to the poor economic conditions of families with working children. Continuous fighting in Afghanistan has destroyed many people's homes, and forced them to flee to safer areas. Many families have sold all they had in order to survive, and parents have left jobs and the means to a livelihood behind.

7. $61 \%$ of children interviewed liked the work they were doing, and $45 \%$ of parents thought their child's work was beneficial in developing skills that would secure the child's future.

Community discussions reinforced the view of most parents that skill development is more important than formal education in order to provide a secure economic base for the family, and assure a future for their child. 


\section{Recommendations}

1. Address the root cause (poverty) and improve family income and resources.

Any sustainable programme to assist working children must involve the family, with the objective to improve the family's economic situation. Credit and savings schemes, income generation, and micro-finance projects should be developed, with the participation of the families of working children.

2. Increase opportunities for the child to acquire useful skills and expand his/her earning power.

Develop more facilities for children to learn technical skills, collaborate with employers of children to develop recognized apprenticeship schemes, and channel children working in the street into work which is more lucrative and sustainable throughout the year.

\section{Provide appropriate educational opportunities for working children.}

Make education available and relevant to working children by taking learning to the workplace. Creative, participatory learning techniques should be used, including health education and life skills. A longer-term objective is to strengthen the capacity of the loca! education system, so that it is attractive and available for working children.

4. Protect children from exploitation and ensure better working conditions.

Help children working on the streets to organise and form collectives, to protect them from abuse and exploitation. Employers should be encouraged to allow regular rest periods for child workers, and to pay them realistic wages for training and work.

5. Promote linkages and collaboration between existing programmes working with vulnerable groups in Mazar, and agencies involved with working children.

6. Promote advocacy and raise awareness about the needs and rights of working children at all levels: with children, parents, employers, community groups, and the local government.

7. Involve children, their families, and local staff and community leaders in the planning and development of services for working children.

8. Take time to plan responses that are based on the reality of the children's lives, and develop programmes that are sustainable. 


\section{Section 1 -- Introduction}

In every country in the world, children work. Children help with household chores, they look after younger children, they work on family farms and in family businesses, and many children work to earn money for themselves or to help support their families.

The International Labour Organization estimates that there are at least 250 million child workers worldwide. Figures which include child domestic work and child workers hidden from view push this figure up to 500 million -- half the children in the developing world. ${ }^{2}$

The scale of the problem has given rise to much international debate, advocacy for rights of the child, and programmes for child workers. While international debate and action is crucial, it is often based on a romantic, northern model of childhood as a time for education and play, with children dependent on adults for protection and economic security.

This northern view of childhood bears little relation to reality for most of the world's children, and is certainly not the norm in Afghanistan. In a largely rural country with strong traditional customs and beliefs, children in Afghanistan are expected to assist with household chores, help in the fields, and work in family businesses as soon as they are able to walk, carry water, and use tools. After years of war, many of Afghanistan's children are the primary providers and protectors for their families, taking over the roles of their fathers or male relatives who have been killed or are away fighting.

With millions of families displaced, economic survival is the primary concern -- education and recreation for children are seen as luxuries that cannot be afforded. As stated by the Head of the Department of Labour and Social Affairs in Mazar, "In our country, when a child is frur or five years old, the parents train them how to work at home or in the fields. Now, with this war, many people have had to leave their homes and land and are displaced. They have no wr.t, so must send their children to the streets for work. They have no other choice."

Most Afghan people report that 20 years ago, it was extremely rare to see a beggar or a child working in the street. Now, after 18 years of war, many women and children have no recourse but to beg or scrounge a living from the street. In Kabul, the streets are full of bu qa-clad women and small children, begging or demanding "baksheesh". In 1996, a Needs Assessment of Children working in the Streets of Kabul identified more than 28,000 children working in the streets. ${ }^{3}$ Now, with Taliban restrictions confining women to their homes, aid workers estimate there may be more than 50,000 child workers in Kabul, working on the streets to scrounge a living.

\footnotetext{
${ }^{2}$ Figures are taken from the New' Internationalist, Issue No. 292 on Child Labour, July 1997.

${ }^{3}$ Needs Assessment of Children Working in the Streets of Kabul, Terre des hommes, June 1996
} 
Mazar-i-Sharif has been spared the continuous fighting and widespread destruction that so many towns and villages in Afghanistan have experienced. For many years Mazar remained a relatively calm provincial city, surrounded by rural countryside. In May of this year, residents in Mazar city experienced fighting in the streets and a brief (three day) take-over by the Taliban. With various factions still vying for power, residents in Mazar are now less certain what the future may hold for them.

Mazar's relative stability amidst a war-torn country and frequent changes of government in Kabul encouraged many displaced families to settle in Mazar. In 1990, the population of Mazar was estimated to be $127,839 .{ }^{4}$ Today, the population is estimated to be between 700,000 and 1,000,000 people, many of them displaced families. $60 \%$ of the families surveyed in this Needs Assessment have been displaced or were refugees.

This influx of displaced families to Mazar and the recent appearance of child workers on the streets prompted SCF to undertake a Needs Assessment of working children in Mazar, in order to provide baseline data for its own programmes and those of other organisations. As stated in SCF's working paper on children in the working world, "intervention strategies must be based on a thorough understanding of the complexity of the reasons children work in particular contexts."

This needs assessment was designed to gather both qualitative and quantitative data on the lives of working children and their families in Mazar city. Specific objectives were:

- To ascertain the prevalence of working children in Mazar-i-Sharif

- To identify the types of work done by children in Mazar, and gather information about their working lives and family situations.

- To evaluate whether or not these types of work are harmful, hazardous, socially damaging, exploitative, or educationally limiting.

- To understand the reasons why children are working

- To listen to the views of the children, their families, and community members

- To determine appropriate means of addressing the problems and needs identified by the Needs Assessment

\footnotetext{
${ }^{4}$ Balkh Province -- A Socio-Economic Profile, UNIDATA, March 1992

${ }^{5}$ Small hands -- Children in the working world, SCF (UK),1997
} 


\section{Section 2 -- Methodology}

\subsection{Selection of Staff}

One expatriate consultant was contracted by SCF (UK) for a period of six weeks to conduct the Needs Assessment and write the report. Two Afghan consultants were selected (one female and one male) to assist with training, supervision, case studies and focus group discussions. 17 surveyors were recruited locally to compile a name list of working children in Mazar, and to conduct a detailed survey of 300 working children and their families. The majority of surveyors were university graduates, with no previous experience in conducting surveys. After completion of the survey, 10 surveyors were retained to assist with discussions with children and the preparation of case studies.

\subsection{Training of Surveyors}

The surveyors were given training over a period of 6 days. The training programme emphasized active, experiential learning, and included: discussions about local attitudes and ideas about childhood and working children; exercises to develop skills in observation, listening, and working with children; training in the use of questionnaires; piloting the questionnaire; and re-training to correct problems encountered during piloting. (A detailed summary of the training programme can be obtained from SCF, Mazar.) Those people selected to prepare case studies and participate in discussions with children were given an additional half-day training.

\subsection{Criteria for defining a 'working child' in Mazar}

Based on discussions held with the SCF(UK) Programme Manager and local views about working children, the following criteria were agreed in order to identify working children in Mazar-i-Sharif:

- The name list and survey would include children working in the streets, in shops, and in factories.

- The child should be between the ages of 5 and 14 (inclusive)

- Children who do not attend school, and spend the majority of the day working

- Children working in the streets should be working independently (i.e. children assisting adult relatives in family work or begging with an adult would not be included in the selection criteria) 


\subsection{Observation and Mapping of Districts}

Surveyors were divided into teams (one male and one female in each team) and sent to all 10 districts in Mazar. Each pair of surveyors was given maps of their district, and asked to walk through the entire district, in order to observe working children and map the areas in which they could be found. Areas where children could be found working in the streets were marked in red, and shops and factories where children could be seen working were marked in blue. In addition to mapping, surveyors were to observe and list what kinds of work children were doing, and the times of day when children worked.

\subsection{Piloting the Questionnaire}

The objectives of piloting the questionnaire were:

- To give surveyors practice in using the questionnaire

- To identify questions or sections of the questionnaire which were inappropriate or difficult to use.

- To revise the questionnaire, if necessary

- To give additional training to the surveyors in the use of the questionnaire

\subsubsection{Methods}

On the first day of piloting, the surveyors were asked to go in teams to their districts, and pilot only 2 questionnaires. They then returned to the training room for checking the questionnaire, feedback, and further training. On the second day of piloting, the surveyors spent the entire morning surveying, and the afternoon checking the questionnaires and receiving additional training. A total of 80 questionnaires were piloted.

\subsection{Conducting a Survey of Working Children and their Families}

A total of 300 working children and their families were surveyed over a period of 6 days, using a questionnaire to gather both qualitative and quantitative data about their work and family situations. The questionnaire used both open and closed questions, and emphasised the children's and families' own views about why the children were working, problems they experienced, and possible alternatives. (For a copy of the questionnaire, please refer to Appendix II) The 300 questionnaires were sent to the ACBAR Survey Unit in Peshawar for data entry and analysis. The finding are presented under Section 3. 


\subsubsection{Problems encountered during surveying}

- The surveyors initially had difficulty identifying the correct children according to the criteria, because the study coincided with the school holidays, and many children who usually do not work were doing part-time jobs on the street (selling water) for 'pocket money".

- Due to the heat, many surveyors found the work exhausting.

- Surveyors initially found it difficult to cope with the curiosity and crowding-around of bystanders, who were interested to know what they were doing.

- The process of interviewing working children and their families inevitably raised their expectations that some form of assistance might be forthcoming. It was difficult for the surveyors to witness the families' poor living conditions and listen to their stories, without being able to offer any definite support.

- Some surveyors had unclear handwriting, or were judgmental during interviews.

\subsection{Creating a Name List of Working Children in Mazar-i-Sharif}

In order to ascertain the prevalence of working children in Mazar-i-Sharif, the surveyors attempted to find all the children working in the streets, in shops, and in factories in all 10 districts of Mazar-i-Sharif. These children's names were added to those obtained from the survey, and data on sex, age, type of work, and educational level of the child were recorded. (This list will remain confidential to SCF, and may be used subsequently to select children for future programmes. The formats used to collect this data can be found in Appendix III)

A total of 1,446 children were discovered to be working, and their names entered on the name list. (This figure is inclusive of the 300 children surveyed.) Children who were hidden from view (i.e. children working in family enterprises or compounds behind closed doors) and children occupied with domestic chores at home were not included in this name list.

\subsection{Case Studies of Working Children}

Five children were selected for more intensive case studies. A team of surveyors met with the child and his/her family to ask permission to observe the family and the child for an entire day. With the agreement of the family, 2 surveyors observed the family and the child at work from 6:00 A.M. until 7:00 P.M. The surveyors each used an observation chart, and subsequently compiled their individual observations and information from discussions with the families to write the case studies. 


\subsection{Individual and Group Discussions}

In order to obtain a wider view about working children in Mazar-i-Sharif, discussions were held with a variety people and community groups. These included:

Individuals: District Presidents in 6 Districts

Head of Education Department

Head of Literacy Department

Head of Labour and Social Affairs Department

Organisations: $\quad$ UNICEF

HABITAT

ICRC

NSBD

Focus Group

Discussions:

Community Fora (Discussions were held with Community Fora participants in Districts 1, 2.4. and 8)

Children's Groups: 6 focus group discussions were held with working children, including a total of 40 children:

3 groups were with children working on the streets

2 groups were with children in mechanic shops

1 group was with children in a raisin factory

Note: All interviews and discussions were conducted in Dari. 


\section{Section 3 -- Findings of the Needs Assessment}

\subsection{Prevalence of Working Children in Mazar-i-Sharif}

In total, 1,446 children were found working in the streets, shops, and factories in Mazar-iSharif. (As mentioned previously, this does not include children hidden from view, or child domestic workers.) Out of the 1,446 children identified, $94 \%$ were boys, and $6 \%$ were girls.

The highest prevalence of working children were found in districts 2,3 and 4 . There were no working children identified in district 10 . A breakdown of the prevalence of working children in Mazar-i-Sharif is summarized in Table 1.

\section{TABLE 1: PREVALENCE OF CHILDREN WORKING IN MAZAR-I-SHARIF}

\begin{tabular}{|c|c|c|c|}
\hline \multirow{2}{*}{ Districts } & \multicolumn{3}{|c|}{ NUMBER OF CHILDREN } \\
\cline { 2 - 4 } & Boys & Girls & Total \\
\hline 01 & 142 & 1 & 143 \\
\hline 02 & 205 & 16 & 221 \\
\hline 03 & 254 & 15 & 269 \\
\hline 04 & 295 & 20 & 315 \\
\hline 05 & 146 & 8 & 154 \\
\hline 06 & 51 & 7 & 58 \\
\hline 07 & 121 & 7 & 128 \\
\hline 08 & 87 & 3 & 90 \\
\hline 09 & 55 & 13 & 68 \\
\hline Grand total & 1,356 & 90 & 1,446 \\
\hline
\end{tabular}

\subsection{Breakdown of Working Children by Sex, Age and Type of Work}

It can be seen from the following table that the majority of working boys are within the age group 11-14 (67\%), and the majority of girls are within the age group 8-10 (49\%). While the detailed survey did not include children less than 5 years, six children under 5 were discovered while compiling the name list. Two of these children were selling water (with older brothers), two were collecting paper, and one was begging .

The majority of boys were engaged in mechanical work (30\%) and selling water (29\%), while the majority of girls were engaged in selling food which they brought from home (40\%) and collecting paper, wood, and other fuel items (34\%). 
Table 2: Breakdown by Sex and Age and Type of Work

\begin{tabular}{|c|c|c|c|c|c|c|c|c|c|}
\hline \multirow[b]{2}{*}{ Type of Work } & \multicolumn{4}{|c|}{ Boys } & \multicolumn{4}{|c|}{ Girls } & \multirow[b]{2}{*}{ Total } \\
\hline & $\begin{array}{l}\text { Age } \\
<5\end{array}$ & $\begin{array}{l}\text { Age } \\
5-7\end{array}$ & $\begin{array}{c}\text { Age } \\
8-10\end{array}$ & $\begin{array}{c}\text { Age } \\
11-14\end{array}$ & $\begin{array}{l}\text { Age } \\
<5\end{array}$ & $\begin{array}{l}\text { Age } \\
5-7\end{array}$ & $\begin{array}{l}\text { Age } \\
8-10\end{array}$ & $\begin{array}{c}\text { Age } \\
11-14\end{array}$ & \\
\hline Selling Water & 2 & 19 & 111 & 268 & 0 & 1 & 5 & 4 & 410 \\
\hline Selling Food & 0 & 12 & 35 & 83 & 0 & 6 & 16 & 14 & 166 \\
\hline Begging & 1 & 4 & 10 & 6 & 0 & 2 & 2 & 0 & 25 \\
\hline $\begin{array}{l}\text { Selling Small } \\
\text { ltems }\end{array}$ & 0 & 4 & 29 & 75 & 0 & 0 & 1 & 1 & 110 \\
\hline $\begin{array}{l}\text { Collecting Fuel } \\
\text { ltems }\end{array}$ & 2 & 5 & 25 & 27 & 0 & 8 & 14 & 9 & 90 \\
\hline Polishing Shoes & 0 & 1 & 5 & 28 & 0 & 0 & 0 & 0 & 34 \\
\hline Cleaning Cars & 0 & 2 & 7 & 33 & 0 & 0 & 0 & 0 & 42 \\
\hline Mechanical Work & 0 & 17 & 111 & 279 & 0 & 0 & 0 & 0 & 407 \\
\hline Carpet Shop & 0 & 0 & 2 & 1 & 0 & 0 & 1 & 1 & 5 \\
\hline Shoe Making & 0 & 0 & 9 & 34 & 0 & 0 & 0 & 0 & 43 \\
\hline Bakery & 0 & 0 & 4 & 14 & 0 & 0 & 0 & 0 & 18 \\
\hline Other & 1 & 6 & 17 & 67 & 0 & 0 & 5 & 0 & 96 \\
\hline Total & 6 & 70 & 365 & 915 & 0 & 17 & 44 & 29 & 1,446 \\
\hline
\end{tabular}

Other types of work included:

$\begin{array}{lrrlll}\text { Raisin Factory } & -- & 21 & \text { Tinsmith } & -- & 2 \\ \text { Tailor Shop } & -- & 13 & \text { Making Sweets } & -- & 2 \\ \text { Carpentry } & -- & 10 & \text { Plumbing } & -- & 1 \\ \text { Cart Driving } & -- & 8 & \text { Making furniture } & -- & 1 \\ \text { Electrical Wiring } & -- & 5 & \text { Shop Assistant } & -- & 1 \\ \text { Ice-cream shop } & -- & 3 & \text { Unknown } & -- & 26 \\ \text { Pulling carts } & -- & 3 & & \end{array}$

Note: Children who sell water during the summer months will often not work during the winter, or will sell food/snacks prepared at home, or work pulling carts.

\subsection{Where are Working Children found in Mazar-i-Sharif?}

Out of the 1,446 working children on the name list, $908(63 \%)$ were found working in the streets, and $538(37 \%)$ were working in shops and factories. The highest concentrations of working children were in districts 2,3 and 4 . Mechanical workshops were prevalent in districts 4 and 7, and were primarily small shops having less than five children per shop. Shoe-making was concentrated in district 5 , and the only large factory (a raisin factory employing 21 boys, aged 11-14 ) is located in district 6 . 
Table 3: Types of Work by District

\begin{tabular}{|c|c|c|c|c|c|c|c|c|c|c|}
\hline \multirow[b]{2}{*}{ Types of work } & \multicolumn{9}{|c|}{ NUMBER OF CHILDREN BY DISTRICT } & \multirow[b]{2}{*}{ TOTAL } \\
\hline & $\begin{array}{c}\text { Dist. } \\
1\end{array}$ & $\begin{array}{c}\text { Dist. } \\
2\end{array}$ & $\begin{array}{c}\text { Dist. } \\
3\end{array}$ & $\begin{array}{c}\text { Dist. } \\
4\end{array}$ & \begin{tabular}{|c} 
Dist. \\
5
\end{tabular} & $\begin{array}{c}\text { Dist. } \\
6\end{array}$ & $\begin{array}{c}\text { Dist. } \\
7\end{array}$ & $\begin{array}{c}\text { Dist. } \\
8\end{array}$ & $\begin{array}{c}\text { Dist. } \\
9\end{array}$ & \\
\hline Selling Water & 44 & 97 & 109 & 65 & 41 & 8 & 24 & 7 & 15 & 410 \\
\hline Selling Food & 14 & 18 & 23 & 30 & 21 & 15 & 13 & 10 & 22 & 166 \\
\hline Begging & 1 & 1 & 10 & 10 & 2 & 0 & 0 & 1 & 0 & 25 \\
\hline $\begin{array}{l}\text { Selling Small } \\
\text { Items }\end{array}$ & 17 & 41 & 19 & 20 & 7 & 2 & 4 & 0 & 0 & 110 \\
\hline $\begin{array}{l}\text { Collecting Fuel } \\
\text { Items }\end{array}$ & 4 & 25 & 1 & 24 & 2 & 2 & 4 & 6 & 22 & 90 \\
\hline Polishing Shoes & 2 & 2 & 20 & 7 & 2 & 0 & 0 & 1 & 0 & 34 \\
\hline Cleaning Cars & 12 & 2 & 10 & 12 & 5 & 0 & 0 & 0 & 1 & 42 \\
\hline $\begin{array}{l}\text { Mechanical } \\
\text { Work }\end{array}$ & 48 & 33 & 45 & 135 & 22 & 7 & 78 & 37 & 2 & 407 \\
\hline Carpet Shop & 0 & 0 & 0 & 0 & 5 & 0 & 0 & 0 & 0 & 5 \\
\hline Shoe Making & 0 & 0 & 0 & 0 & 43 & 0 & 0 & 0 & 0 & 43 \\
\hline Bakery & 0 & 0 & 0 & 0 & 0 & 3 & 0 & 15 & 0 & 18 \\
\hline Other & 1 & 2 & 32 & 12 & 4 & 21 & 5 & 13 & 6 & 96 \\
\hline Total & 143 & 221 & 269 & 315 & 154 & 58 & 128 & 90 & 68 & 1,446 \\
\hline
\end{tabular}

\subsection{Educational Level of Working Children}

None of the working children identified in this Needs Assessment were currently attending school. However, $496(20 \%)$ had previously attended school. Out of the 300 children interviewed more extensively, $138(46 \%)$ had previously attended school, and their educational level is summarized in Table 4:

\section{Table 4: Educational Level of 300 Children Surveyed}

$\begin{array}{lr}\text { Never attended school } & 162 \\ \text { Class 1 } & 38 \\ \text { Class 2 } & 41 \\ \text { Class 3 } & 28 \\ \text { Class 4 } & 21 \\ \text { Class 5 } & 9 \\ \text { Class 6 } & 0 \\ \text { Class 7 } & 1\end{array}$

The reasons given why children were not attending school were:

$\begin{array}{lr}\text { Economic problems } & 61 \% \\ \text { Displacement } & 20 \% \\ \text { Child does not like school } & 15 \% \\ \text { Other reasons } & 4 \%\end{array}$




\subsection{Ethnicity of 300 Children Surveyed}

\begin{tabular}{lcc} 
Ethnicity & No. of Children & \% of Children \\
\cline { 2 - 3 } Tajik & 181 & $60 \%$ \\
Hazara & 67 & $22 \%$ \\
Uzbek & 25 & $8 \%$ \\
Pashtun & 20 & $7 \%$ \\
Arab & 7 & $2 \%$
\end{tabular}

\subsection{Working Lives of the Children}

\subsubsection{Types of Work}

As detailed in Tables 2 and 3, the most common types of work for boys was working/training in small mechanical shops ( $30 \%$ of boys) and selling water ( $29 \%$ of boys). The majority of girls sold food which was prepared at home $(40 \%)$, or collected paper, wood, and other fuel items $(34 \%)$.

\subsubsection{Length of Time Children had been Working}

Out of the 300 children surveyed in detail, the majority (38\%) had been working for less than 3 months. These were primarily children working on the street, who were taking advantage of the hot, dry weather to sell water, which can be quite lucrative (refer to Table 7). During the winter, many of these children do not work, or they switch to selling food (bulani, potatoes, or bread) brought from home.

\section{Table 5: Length of Time the Children have Worked}

\begin{tabular}{|c|c|c|c|c|c|}
\hline Time & $<3$ Months & $4-6$ Months & 6 Mos - 1 Year & $1-2$ Years & $>2$ Years \\
\hline Boys & 102 & 55 & 28 & 44 & 43 \\
\hline Girls & 13 & 4 & 4 & 4 & 3 \\
\hline Total & 115 & 59 & 32 & 48 & 46 \\
\hline
\end{tabular}


The majority of the children who worked on the streets tended to work 7 days per week, and were away from home 9-13 hours per day. They often rested or ate between 12:00 and 2:00 when the sun was at its hottest, and frequently took breaks during the day to talk or play with other children. Children working in shops and factories ususally worked a 6-day week, and from 7:00 or 8:00 in the morning until 5:00 or 6:00 in the evening.

Girls tended to work less hours than boys, returning home as soon as they had finished selling their food, or collected sufficient fuel items. A summary follows:

No. of Days Worked per Week

7

6

5

4

$1-3$

No. of Hours Worked per Day

$>15$
15
14
13
12
11
10
9
8
7
6
5 or less

No. of Children

180

114

4

2

None

No. of Children

None

1

11

46

49

67

36

39

10

18

8

15

\subsubsection{Income Earned by Children per Day (Based on 300 children interviewed)}

The range of income earned by the children varied considerably, from less than Afs 2,500 per day, to more than Afs 50,000 (= US $\$ 1$ ). The types of work which earned the most money were cleaning cars and selling water, and the work for which children received low amounts were mechanical work and carpet shops. $95 \%$ of the children said that they gave the money they earned to their families or the relatives with whom they lived. The other $5 \%$ said that they kept the money for themselves. The income earned by children is summarized in Tables 6 and 7. 
Table 6: Income Earned by Children per Day

Income per day (Afs) $\quad$ No. of Children

$<2,500 \quad 45$

$2,500-5,000 \quad 15$

$5,000-10,000 \quad 16$

$10,000-15,000 \quad 32$

$15,000-20,000 \quad 23$

$20,000-25,000 \quad 51$

$25,000-30,000 \quad 15$

$30,000-35,000 \quad 42$

$35,000-40,000$

$40,000-45,000 \quad 26$

$45,000-50,000 \quad 1$

$>50,000 \quad 30$

Table 7: Income Earned According to Type of Work (Afs per day)

\begin{tabular}{|c|c|c|c|c|}
\hline Type of Work & No. of Children & Lowest & Highest & Most Comn \\
\hline Selling Water & 112 & 10,000 & 100,000 & $20-30,000$ \\
\hline Selling Food & 63 & 10,000 & 80,000 & 20,000 \\
\hline Mechanical Work & 46 & 1,000 & 50,000 & $2-3,000$ \\
\hline Selling Small Items & 20 & 5,000 & 60,000 & 20,000 \\
\hline Cleaning Cars & 15 & 10,000 & 100,000 & $30-50,000$ \\
\hline Shoe Making & 7 & 10,000 & 15,000 & 10,000 \\
\hline Carpet Shop & 5 & 2,000 & 3,000 & 2,000 \\
\hline Begging & 4 & 7,000 & 20,000 & 12,225 \\
\hline Polishing Shoes & 4 & 20,000 & 30,000 & 30,000 \\
\hline
\end{tabular}

\subsubsection{Eating Habits of Children while Working}

Out of the 300 children surveyed, $287(96 \%)$ reported that they ate during working hours. When asked what they usually ate and how they obtained the food, these were the most common replies:

\section{Type of Food}

Bread and tea

Soup

Vegetables

Fruit

Fast food*

Rice

Pulses
No. of Replies

268

65

56

34

20

20

8

\section{How Food is Obtained No. Replies}

From the bazaar 166

The shop/factory owner provides 60

I bring food from home 57

Begging

4

* Fast food = boulani, chips, eggs, potatoes, pakora, etc 


\subsubsection{Do the Children Have Free Time while Working?}

When asked whether or not they had free time during the day, 195 children said 'yes' $(65 \%)$, and 105 said 'no'. Of those who have free time, 126 said they have free time in the afternoon, 44 in the morning, and 25 in the evening (after 5:00). The children working in shops and factories often took more time for rest (many would stop for lunch and a rest after lunch), while the children working in the street had more time for talking and playing with other children when they were not busy. When asked what they did with their free time, these were the replies:

\section{Activity during Free Time}

Fetching water

Housework

Playing

Resting

Shopping

Collecting firewood

Praying and studying Quraan

Other

\section{No. of Replies}

70

70

24

15

6

3

2

5

\subsubsection{Problems and Difficulties Encountered by the Children during Work}

$68 \%$ of the children surveyed said that they did not have any problems during work. Of the $32 \%$ who did experience problems, these were the most common complaints:

\section{Problem}

Very hot sun

Carrying water and ice (heavy)

Long distance to walk to the bazaar

No payment

Carrying food (heavy)

Other children teasing

\section{No. of Replies}

When asked in a different way what special difficulties they faced during work, $60 \%$ said they had difficulties:

\section{Difficulty}

Carrying water and ice (heavy)

Walking long distances

Carrying food (heavy, and sometime spills) 24

Carrying other heavy items

The work is hard

Washing cars is difficult

Finding firewood

Very hot sun

\section{No. of Replies}


Out of the 300 children surveyed, $34(11 \%)$ said they had been threatened or beaten during work. 32 children said they were beaten by security guards after the guards refused to pay for water or services (17 children), because the guards said they were blocking the road (12 children), or because the child was taking water from a pipe. In 2 cases, security guards had demanded money from the children, and threatened them when the child did not pay. Two children said they had been beaten by their master/trainer for making mistakes in their work.

\subsection{Family Circumstances (Summary of information from 300 family interviews)}

All of the 1.446 children who were identified had a place to sleep at night, most of them with their own families. Out of the 300 sample group, 290 children slept in his/her home, 9 children stayed with relatives, and 1 child slept in a relative's factory. Working children in Mazar-iSharif are clearly not street children, but children who live at home and go to work in the streets, shops and factories of Mazar. Afghan religious and cultural traditions ensure that relatives look after each other and offer refuge to children without a home.

228 children ( $76 \%$ ) were living with both of their parents, 62 children came from single-parent families, and 10 children were orphaned and living with relatives (parents had both died or were missing).

\section{Table 8: Information About Parents}

Father

Living with family
Dead Missing
Mother

Living with family Dead Missing

No. of

families:

235

59

6

283

12

5

\subsubsection{Size of Families}

For this Needs Assessment the size of a family was defined as parents + their own children. Most families had between 6 and 10 family members, as summarized in Table 9.

\section{Table 9: Family Size}

No. of family members (parents + children)

$\begin{array}{lllllllllllll}1 & 2 & 3 & 4 & 5 & 6 & 7 & 8 & 9 & 10 & 11 & 12 & >12\end{array}$

No. of

families: $\quad \begin{array}{lllllllllllll}2^{*} & 5 & 4 & 15 & 23 & 43 & 63 & 54 & 44 & 26 & 12 & 6 & 3\end{array}$

* These 2 children were lone orphans, and surveyors did not include relatives as familiy members. 


\subsubsection{Employment of Parents}

\section{Table 10: Employment of Parents}

$\underline{\text { Status }}$

Father only employed

No parent employed

Both parents employed

Mother only employed

\author{
No. of Families
}

126

95

44

35

\subsubsection{Income of the Families}

During discussions with families, they were asked to calculate their total monthly income (the total earned from all family members who were receiving money). Out of the 300 families, the majority of families earned between Afs 500,000 (US \$10) and Afs 2,500,000 (US \$50) per month, as summarized below.

During focus group discussions, we asked people to estimate how much money a family of 7 would need to live for one month. Estimates varied, but most people agreed that a family of 7 would need Afs 6,000,000 per month, if they only ate bread, tea, and yogurt. If the family were to eat meat once a week and some vegetables, send their children to school, and be able to afford health care, they would need approximately Afs 12,000,000 per month. The Head of the Education Department estimated that it costs Afs 1 million per child to register and prepare for school (uniform, books, etc.) and a further Afs 100,000 per month for stationery. Yet, a teacher working for the Education Dept. receives only Afs 100,000 per month as a salary -- less than most of the working children.

\section{Table 11: Total Monthly Income of Families Interviewed}

\section{Average Income per Month (Afs)}

$$
\begin{gathered}
<500,000 \\
500,000-1,000,000 \\
1,000,000-1,500,000 \\
1,500,000-2,000,000 \\
2,000,000-2,500,000 \\
2,500,000-3,000,000 \\
3,000,000-3,500,000 \\
3,500,000-4,000,000 \\
4,000,000-4,500,000 \\
4,500,000-5,000,000 \\
>5,000,000
\end{gathered}
$$

No. of Families 
In order to increase family income, $56 \%$ of the families had more than 1 working child:

No. of families with 1 child working:

133

No. of families with 2 children working: $\quad 128$

No. of families with 3 children working: $\quad 33$

No. of families with 4 children working: 4

No. of families with 5 children working: $\quad 2$

The working child or children were the main source of income in $55 \%$ of the families:

\section{Main Source of Income No. of Families}

Child 166

Father 119

Mother 11

Other relative 4

\subsubsection{Length of Time the Families have lived in Mazar-i-Sharif}

$49 \%$ of the families interviewed had been displaced (146 families), and $12 \%$ were returned refugees. The remaining $39 \%$ had always been resident in Mazar-i-Sharif. The majority of displaced families came from Kabul (93 families).

Many of the displaced families had moved to Mazar-i-Sharif many years ago, with only $27 \%$ arriving during the past year. Table 12 summarizes the length of time displaced families have been living in Mazar.

Table 12: Length of Time Displaced Families have lived in Mazar

$\begin{array}{lllllllll}\text { Length of } & <6 & 6-12 & 1-3 & 3-5 & 5-10 & 10-15 & 15-20 & >20 \\ \text { Time: } & \text { Months } & \text { Months } & \text { Years } & \text { Years } & \text { Years } & \text { Years } & \text { Years } & \text { Years }\end{array}$

No. of

Families

$11 \quad 28$

29

$35 \quad 35$

$3 \quad 3$

2

\subsubsection{Health of the Families}

This Needs Assessment did not focus on health issues or use objective indicators to measure the health of working children. The surveyors were given only basic training on signs and symptoms of malnourished children, and identified only 6 children out of 300 as being malnourished. However, 162 families $(54 \%)$ reported that a least one child had died from sickness/disease. In 12 families, children had died due to war/fighting. 


\section{Section 4 Case Studies of Working Children}

"My biggest wish is that I can have a good metal workshop and be the trainer of a metal workshop. Also, I would like to continue my studies. I would also like to have a special friend, but I don't have any because poor children do not have friends"

It is difficult to capture the reality of working children's lives from surveys, statistics, and tables. Their lives and wor': are many-faceted, and it would be wrong to give the impression that the work these children do is all 'good' or all 'bad'. For many children, each day brought moments of difficulty, but also times when they could play with other children, rest, learn something, and experience independence.

In this section, we chronicle 'a day in the life' of five working children, and let the children speak for themselves.

Note: The names of the children have been changed to protect their identity. 


\section{CASE STUDY -- MOHAMMAD FAWAD}

Fawad is an 11-year-old boy who was displaced from Kabul to Mazar. He spends his days in the streets of Mazar cleaning cars. He told about his life and work like this:

I do not remember much about my life when I was very young, but my mother has told me this information. I was born in Kabul city 11 years ago in a poor and uneducated family. The time passed very well, and we lived in a calm and comfortable house. When I was 6 years old and my older brother was 7, my father passed away and left my mother alone with 7 children ( 4 boys and 3 girls). We were small, and my mother had to sell the things which were in the house to run the family and save us from poverty. So when everything was gone, the living conditions were very bad, and forced us to leave Kabul for Bamiyan, where my parents were born -- it was their homeland. We were too small to work in the fields and run the family. So after some time, my mother decided to leave there for Mazar city. It is completely clear that in Mazar, children can do some active work in the town. That is why we came here.

In Mazar city we live in Tasady Kamaz, where maky dispiaced families live. The UN gave a tent for each family, in which to pass the four seasons in Mazar. During that time, my brother and I started working on the street, collecting paper, wood, and other fuel items. We did this for about 6 months, and went to all the places where these things were sold around our area. In this way, I could help support my poor family and we passed a very cold winter under the tent.

When the winter passed, we sold our tent and built two small rooms. They were very cold and damp without electricity. For a toilet we go to a place which is far from our living room. There are three toilets there for 25 families. The toilets do not have doors, but we hang a curtain there.

I started cleaning cars about 14 months ago in the streets around the Shrine of Azrat Ali. The first day when I came to the street for cleaning cars, it was very difficult and my elder brother worked with me. But I had to get used to it, because there was no other way for us -- only this. Cleaning big cars is very difficult, even impossible. I became very disappointed when some drivers told me that I could not clean very well and pushed me to go away. Sometimes, I walked all day to find a car to wash. I have to wait very long hours, and it makes me very sad. I tell to my heart that one day our Great God will take away this sadness. It is very hard to work under the hot sun without having any special food. I only eat bread with water, or sometimes a glass of tea. My family eats bread, tea, and rice, without meat or vegetables.

In one day I can earn about Afs 40,000 , sometimes more or less depending on the cars. I give the money to my mother. Because we are young, my mother runs the family with our money.

I have one desire in my heart but I do not know whether it will ever happen. I am very interested in technical work or mechanical work, but I can't go there for training because I have to work for my family. In future, I hope I will be a mechanic and run a mechanical shop. 


\section{A DAY IN THE LIFE OF FAWAD}

6:00 A.M. When Fawad got up, he washed his face and hands. Without having breakfast, he left the house for his work. He took a bus to the centre of the city, and paid Afs 2,000 to the bus driver. He got down and started washing cars.

7:00 A.M. During this time, Fawad washed two car's tyres, and cleaned inside the cars. They paid him Afs 6,000. From this money, he bought one bread to eat.

8:00 A.M. Fawad washed 3 cars, and received Afs 8,000. He was very active.

9:00 A.M. Fawad washed another car whose owner was very rich and paid him Afs 10,000. While Fawad waited for other cars, he talked to other children. The children talked about a film, and Fawad was very interested.

10:00 A.M. During this time Fawad was free, and came to us and talked about his work. Then he went again in the street to look for cars to wash.

11:00 A.M. Fawad washed four tyres of a car and cleaned the inside, and received Afs 4,000 . Then he sat down in a quiet place and was resting and thinking.

12:00 Noon Fawad brought bread and ate it with water. He looked very tired, sat under a tree and looked around.

1:00 P.M. Fawad went to the shrine at Azrat Ali to bring water. He washed a car and received Afs 5,000 from the owner.

2:00 P.M. Fawad was free and waited for cars. He also counted the money he earned.

3:00 P.M. Again Fawad washed a car and received Afs 5,000. He looked very active and happy while he worked.

4:00 P.M. Fawad spent about 20 minutes washing a car, and the rest of the time he ran on the street and played with other children.

5:00 P.M. Fawad washed a car together with other children and received Afs 5,000. Then he went to a side road and counted his money.

6:00 P.M. While Fawad was counting his money, the other children who were cleaning cars hid his pail. Fawad searched for it, but could not find it. Since he was free, he again counted his money -- he had earned Afs 40,000 and spent Afs 7,000 on food.

7:00 P.M. Fawad found his pail and went to the bus station. He called out "Tasady Kamaz! Tasady Kamaz!" for the bus driver, so did not have to pay.

8:00 P.M. Fawad arrived home. He washed his hands and face, ate bread and yogurt, and went to sleep. 


\section{CASE STUDY -- MASSUDA}

Massuda is a girl of nine years, who has spent many days of her life collecting potatoes from the market and selling them. She talks about her life like this:

I am living with my father, mother, two brothers and four sisters in a rented house, for which we pay Afs 150,000 per month. My father is working as a porter in Mazar city. My mother does household chores. Also, some days my mother gets some clothes from neighbours and takes them to the bazaar to sell. After selling the clothes she gets some money from our neighbours, and then buys something needed for the family.

We used to live in Kabul. During the fighting in Kabul my father lost his eye due to a rocket attack. So we had to leave our home and go to Kunduz. We were living in a village called Shaikh Taj Timor. Our life was going on well then, and we were all living comfortably.

But after some time, the fighting started in Kunduz too, and my older brother who had gone to bring hay for the cows died as a result of a mine explosion. After my brother's death, the fighting started again. and all our property was looted. So we all fled to Mazar city. On the way to Mazar, my younger brother passed away. After living in Kunduz for three years, we had to move to Mazar because of the severe conflicts.

Because we are poor, we are living in a rented house which only has one room, and has no water tap or well. But we are getting water from the well located in our neighbours house. Also, we have no toilet, but my father has dug a hole in the ground and we are using that. My brother empties it with a wheel cart.

In the summer, we all sleep out in the yard, but in winter all nine people sleep in one small room. In the summer inside the room it is very hot, but in winter the floor of the room gets very wet and damp. It is very difficult for us because we all have foot ache from the damp floor.

At first I always asked my mother to let me got to school, because I was eager to be at school. But because of having no school in the district where we lived, I was not able to go to school. Now, because of the economical problems, they won't allow me to go to school.

I started to work to help with my family's expenses. I usually collect potatoes from the bazaar and then after boiling them, I sell them in the bazaar. I get 10,000 Afs and give it to my mother to buy some things for the family. My work is hard and boring, especially when the shopkeepers unload the car full of potatoes, and I have to collect those which fall down. I plan to continue my work until my family has no more economic problems. Then I would like to start learning and go to school.

The meals we usually have are bread and tea, sometimes with sugar and sometimes without. Now and then we eat nothing and go to sleep. For a long time we have not eaten rice or meat. Purchasing delicious things is very hard because they are too expensive. Even buying oil is very hard.

I am healthy, but my younger brother has a testicle problem, and we have no possibility for his treatment.

I am eager to learn tailoring, to be able to make my own clothes and clothes for my sister. I would also like to be a doctor, to serve my people. I wish we could have calm and peaceful conditions, and have no more war in our country. 


\section{A DAY IN THE LIFE OF MASSUDA}

6:00 A.M. After getting up from bed, Massuda went to the toilet and washed her hands and face. She then washed the tea glasses and ate breakfast (tea and bread) with her mother. After having breakfast, she collected the glasses and washed them. She went with her brother to Mandawi by foot with their bags. It was very far to walk.

7:00 A.M. On the way, she spoke to her brother and drank some water from a jar. After she entered Mandawi, she began to collect potatoes. She had to wait a long time, because there were very few. She looked for potatoes everywhere, and talked with her friends.

8:00 A.M. After the cars and trucks unloaded their potatoes, Massuda collected the potatoes that fell on the ground. Then she went home with her brother. Along the way, they collected paper and small sticks for burning. They drank water and walked slowly, looking at the ground for fuel to collect.

9:00 A.M. When Massuda got home, she gave the potatoes to her mother. She then went inside and started drawing. Then she brought water and boiled the potatoes.

10:00 A.M. Massuda went into the room and brought the plates which she needed for the potatoes. She then went to the bazaar with the potatoes. She peeled and cut the potatoes, and put them on plates and covered them with cotton cloth.

She sold one plate of potatoes for Afs 1,000.

11:00 A.M. She continued to sell potatoes. She was sitting in a place where there was no shade. She earned Afs 9,000 and looked happy. She finished selling her potatoes, and left to go home. Along the way, she bought a small piece of watermelon for Afs 2,000 and ate it on the street.

12:00 Noon When Massuda got home, she gave the money to her mother, and then got her little sister to calm her. Then she got a bucket to bring water from her neighbour's house. She drew a pail of water, and brought it to her house. Then she started drawing pictures, with much interest. During this time, everyone was having bread and tea individually.

1:00 P.M. Massuda went to lie down on a mattress which had no pillow, and after a short time she fell asleep. Many flies were buzzing on her face, but she remained deeply asleep. She had much sweat on her face while sleeping.

2:00 P.M. Massuda continued to sleep and was very calm. The mother was fanning the children while they slept.

3:00 P.M. Massuda got up and started drawing pictures. She did not let the other children touch the pencils. Then she got ready to go to the bazaar again.

4:00 P.M. Massuda walked alone to the bazaar to collect potatoes and onions. She waited for cars and trucks to come, and she collected the potatoes that fell. She was running quickly, as she was afraid the truck drivers would scold her. 
5:00 P.M. Massuda walked to her home, and seemed very tired. She took a piece of bread and tea to eat, and then she started playing with her small sister.

6:00 P.M. Massuda went to bring water from the neighbour's house for her mother, who was busy washing clothes. After that, $M$ was free, and sat in a corner of the yard.

7:00 P.M. Massuda helped her mother to prepare the dinner. Their dinner was tea, bread, and salad.

8:00 P.M. Massuda was busy eating and talking with her family. All were laughing.

After dinner, the children went to sleep.

\section{CASE STUDY - MURAD}

Murad is a ten-year-old boy working as a water seller in Mazar City. He told his life story like this:

My name is Murad and I am 10 years old. I was born in Khair Khana district of Kabul city, in poor circumstances. When I was 4, we were displaced to Mazar and left everything we had there, as a result of conflicts between different factions.

We found Mazar a calm and comfortable place for living. We have been living here for over 6 years. Our house is situated behind the jail. The number of people in our family is five. My father is 40 years old. Before, he was working as an officer in Kabul, but now he is working in the bazaar, selling vegetables. My mother is 35, and does household chores. My older brother who is 16 followed school until class 5 , but now he also works in the bazaar, selling food. My other brother is 15 , and followed school until class 4 . He now sells small items in the bazaar. I also was in school until class 2, but had to leave because of poor living circumstances.

The house in which we are living contains 3 rooms, a corridor, and a basement. The house is newly-built and not completed. We pay the house owner Afs $1,000,000$ per month. Since the weather is so hot, we all sleep outside in the yard. We have a toilet in the corner of our house, and we get water from the well inside our yard.

I work every day from 7:00 in the morning until 6:00 P.M. I earn Afs 30,000 which I give to my father to buy things that the family needs. The lunch I have every day is a piece of bread which I bring from home, and a piece of melon which I buy in the bazaar. The main problem I face in my work is to carry the full thermos and walk in various sections of the city.

I like very much to watch TV, but we don't have a TV at home. I also like playing with other children and swimming. 


\section{A DAY IN THE LIFE OF MURAD}

6:00 A.M. At 6:00 after Murad woke up, he washed his face and hands. In the yard of the house, he and his brothers ate the food which was left from the night before. He then got ready for going to his work place.

7:00 A.M. Murad bought some ice from an ice-cream shop for Afs 4,000, put it in his thermos and filled the thermos with water. He went to his place of work, and sold the water. Because the weather was so hot, he went to the shade and continued his work.

8:00 A.M. Because it was still early morning, not many people were buying water. So Murad played with other children, and walked with other children for awhile. He sold only 2 or 3 glasses of water.

9:00 A.M. The weather became warmer, and other water sellers appeared from the other side of the city. They disturbed Murad and told him not to stay and work in that place. So Murad carried his thermos with difficulty from one place to another, calling "Ice water! Ice water!"

10:00 A.M. The water in his thermos was almost finished, and he went to another place to try and sell his water before it got warm. Finally, he finished selling all his water.

11:00 A.M. Murad again went to an ice-cream shop, and bought ice for Afs 3,000. He filled the thermos with water, and went to a very crowded area to sell his water.

12:00 Noon Murad bought a piece of melon for Afs 2,000 and ate it, along with a loaf of bread which he brought from home. Since the weather was very hot, many people crowded around him to get water, and the shopkeeper shouted at him to move from that place.

1:00 P.M. Murad continued his work, and soon the thermos was empty. He sat down in a corner, and counted his money. He had Afs 16,000.

2:00 P.M. After counting his money, Murad seemed tired and did not want to continue his work. So he sat down for a while to rest.

3:00 P.M. He filled his thermos for the third time, and bought ice for Afs 4,000. He went to another place called KeFayet Market, and started his work there. The weather was very hot, and sweat was flowing down his face.

4:00 P.M. People were coming from every part of the city, and some of them bought water. Murad was selling water and talking with other children at the same time.

5:00 P.M. The water from his thermos had become warm, and people did not want to buy the water. So Murad had to sell his water for half price.

6:00 P.M. The water from his thermos was finished, so he went to another place, put his thermos in front of himself, and counted his money. He had earned another Afs 15,000. At 6:30 he left to walk to his home.

7:00 P.M. Murad arrived home at 7:00, and gave his money to his mother. He then went to wash his face and hands. He was very tired, and lay down to rest. 


\section{CASE STUDY -- NAJIBA}

Najiba is a 12-year -old Afghan girl, who spends her days collecting wood, paper and other fuel items from the streets in Mazar-i-Sharif. She told her life story like this:

My father was a farmer in Chemtal sub-province, and I was born in Chemtal. After the start of the war, we came to the center of Marzar city. We had our own house in Chemtal, but after the war started we were displaced. I was small at that time and I do not remember much about the war. But my mother told me about the bad situation at that time. Our house was completely destroyed by the war, and all our property was looted. In this war, one of my uncles and two of my cousins were killed.

Now my father is busy with selling chickens, and my mother does home chores. I have four brothers and two sisters. My elder brother has a skin disease, and works with my father to sell chickens. Three of my brothers are small, and my sisters are helping my mother in home chores.

Now we are living with five other families in a yard, and we pay Afs 100,000 per monts: We have only one sitting room and one corridor, which are very old and hot. The wooden beams on the ceiling of the room are ancient and broken, and we worry that it may collapse. Because of the hot weather, we spend all day under a tree which is in our house, and at night we sleep in the yard.

All of the six families which are living in this yard are using one toilet, one bathroom, one kitchen, and one well of water. Because of this, we have a lot of difficulties. The owner of the house fights every day with us, and he tells us repeatedly to leave the room. But we don't say anything because we are afraid.

One day, my father brought two chickens into the yard and one of these chickens ate the house owner's tomatoes. The owner of the house became very angry and fought with us again. So, my father is trying to find another room to rent.

Usually, we eat ladies fingers, potatoes, bread, tea, and yogurt. My father's income is not enough for paying the rent and buying some things for the family. So, I am working too. My job is to collect paper, pieces of wood, manure, and bushes. I do not like this work and I feel shame. But what should I do?

I am not allowed to go to school, because my father is illiterate and he does not let me go to school. Also, my father is saying every time that we are homeless and displaced, so while we are moving from place to place you can not continue going to school. 


\section{A DAY IN THE LIFE OF NAJIBA}

5:00 A.M. When Najiba got up early in the morning, she took ablutions and then she prayed. At 5:30 she took her basin for collecting fuel items towards Gozari Gala Jawaz Khana.

6:00 A.M. There were a lot of donkeys loaded with bushes at Gala Jawaz Khana. When people buy the bushes, Najiba collects the pieces that fall in the street, and takes them to her home to make a fire.

7:00 A.M. Najiba returned to her home and washed her hands. She showed us the pictures which she had drawn. She laughed and told about each picture. She spread the fuel items under the sun to be dried.

8:00 A.M. Najiba took bread from one of the table cloths and ate ladies fingers and bread with her small brothers under the shade of a tree. Then she came and took the teapots from the corridor, and went back outside.

9:00 A.M: She took out the tea glasses and washed them with water, and put them on the chair in the corridor. Then she took the kettle, filled it with water, and spread water around the room to cool it.

10:00 A.M. Najiba swept the area, and then took her small brothers and bought ice-cream. She then helped her big sister cook the lunch, and played with her brothers.

11:00 A.M. After playing, Najiba washed her hands with water and soap. She is careful about cleanliness, washing her hands after each duty. She then prepared the dishes for lunch.

12:00 Noon She brought the basin to wash her brothers' hands, and set the table. Then they ate ladies fingers with bread, and then melon.

1:00 P.M. Najiba slept on an old bag in the corridor.

2:00 P.M. Najiba continued to sleep, but the flies and mosquitoes were disturbing her, and she turned from one side to the other.

3:00 P.M. The weather was very hot, but Najiba continued to sleep until 3:30. At this time she woke up. She took ablutions and prayed.

4:00 P.M. Najiba again took the basin with which she collects fuel from the streets, and went to Gozari Gala Jawaz Khana. From there, she started to collect wood, manure, and papers. She carried everything to her home.

5:00 P.M. When she returned home, she washed the dishes they had used for lunch.

6:00 P.M. Najiba watered and swept the yard of her house. 


\section{CASE STUDY -- AZIZ}

Aziz is a 13-year-old boy who has been working in a metal workshop in Mazar for the past 3 years. His father died 8 years ago and his mother left the family. Aziz tells about his life like this:

When I was five, I lost my father in the war. My father was in the military service. After he died, we had a very bad life. We lived in a rented house in Kabul with my older brother and my mother. After 5 months, my younger sister was born. Sometimes we did not have any food to eat. After some time and much fighting in Kabul, the military people looted our house, and we were displaced to Mazar in order to save our lives.

In Mazar, we lived with my grandfather and grandmother in a camp for displaced people from Kabul. My grandfather entered me and my brother in school, and we studied until class. four. But due to our bad economical situation, we could not continue our studies. We did not have money for clothes, books, notebooks and pens that we needed for school. Also, my mother got married for a second time, and she left us. My grandfather could not pay for our studying anymore, and so my grandmother introduced us to a metal workshop.

At first it was too difficult for me in the workshop, because I was not familiar with metal work. Also, the material that we used during work was very heavy, and I suffered a lot. But I have to do this work, otherwise our family and I would be hungry.

My older brother also left the school and went to a carpentry shop. My brother and I give our earnings to our grandfather because we live in his house and he prepares our daily food and expenses. In our house there are three families living, and 14 members. Sometimes, my uncle's wife helps me in reading and writing.

It is a very long distance from our house to the workshop, which is difficult for me. I also have to bring water from far away, because the water in our well is salty and useless. I would like to play with other children, but I can not find the opportunity to do that, because early in the morning I go to the shop and come back to the house late at night.

My worst memory is when I lost my mother for her second marriage. Now she does not live with us. The other bad memory is when we had to leave school because we did not have enough money. I can not remember any good memories.

My biggest wish is that I can have a good metal workshop and be the trainer of a metal workshop. Also I would like to continue my studies. I would also like to have a special friend, but I don't have any because poor children do not have friends. 


\section{A DAY IN THE LIFE OF AZIZ}

6:00 A.M. At 6:00 Aziz was ready to go to the workshop. He went by foot from his house to Sayed Abad station. After waiting, he got on a bus and got off in Sarak Pul-i-Howai.

7:00 A.M. Aziz went by foot from Pul-i-Howai to the shop, and arrived at 7:00. After changing clothes, he greeted the owner and each trainee was given work. Aziz was given heavy tools, and had to beat and smooth the iron for making a door.

8:00 A.M. Aziz continued to pound the iron for making a door.

9:00 A.M. Work continued. During work, the children would sometimes go outside the shop. Sometimes they played with their work tools, and would talk with each other. They drank a lot of water, and often cleaned their sweat with a cloth or their sleeves.

10:00 A.M. The smoothing and beating of iron continued.

11:00 A.M. At this time. a man came with a donkey cart, and asked them to fix the shoes of the donkey. Aziz helped the workshop owner do this work.

12:00 Noon Aziz looked very hungry and tired. At 12:10 they started eating ladies fingers and bread which was prepared by the owner of the shop.

1:00 P.M. After drinking tea, each trainee went to different places for rest. Aziz went to sleep and was snoring a lot.

2:00 P.M. While sleeping, Aziz turned from one side to the other, but eventually became comfortable.

3:00 P.M. At 3:00 the trainees started working again. While he was working, Aziz drew some pictures of doors and cupboards on the ground.

4:00 P.M. Aziz continued the smoothing and beating of iron with a heavy hammer and tools. The owner of the shop looked after Aziz, and showed that he was happy with his work.

5:00 P.M. Aziz shook his hands and his body to relax and remove his tiredness. He continued to work.

6:00 P.M. Aziz changed his work clothes, and got ready for going home. He left to walk to his home.

7:00 P.M. At 7:00, Aziz reached home, and looked very tired. His grandmother brought him some tea, but he was too tired, and lay down on the floor of the house.

8:00 P.M. After eating dinner (potatoes and sauce), Aziz went to sleep in the yard. 


\section{Section 5 Attitudes and Perceptions about Working Children}

\subsection{Children's Views about their Work and Lives}

"When people gather around us, it is very enjoyable, and I like it very much. I also like to count my money at the end of the day -- then I feel cheerful."

I like repairing parts of cars, but it is very difficult to remove old, rusted screws or to lift heavy engines. If we break a part, the shop owner gets angry."

The profession we are learning now is useful for our future, but it is also useful to go to school. If we're illiterate, we are blind. We want to learn both knowledge and a profession, to make our future brighter."

-- Children's views from focus group discussions

The majority of children (79\%) said that the reason they started working was because their families were poor, and had economic problems. $9 \%$ said they were working/training because they were interested to learn a skill, and $6 \%$ said their parents had advised them to work.

$61 \%$ of the children interviewed said that they liked the work they were doing. All of the children doing mechanical work said that they liked their work, as did the children in the carpet shop. $39 \%$ of children selling food and water also said that they liked their work.

The $39 \%$ of children who did not like their work were asked what they would prefer to do. These were their answers:

\section{What the Children would Prefer to Do}

Attend school

Shopkeeping

Selling fruit \& vegetables

Learning a skill

Tailoring

Vendor

Selling food/water

Mechanic

Driving

Housework

Job with more income

Polishing shoes

Working in hotel

\section{No. of Replies}


In discussions about the kind of assistance that could help them or their families, almost all the children requested giving direct aid to improve their families' economic conditions, and assistance to procure materials needed for school:

"If our families could be provided with essential things like flour, oil, tea, sugar, firewood, and mattresses, then we could stop work and go to school. but for school we also need to have special clothing, and books, notebooks and pens. You would need to give these things to us and our families."

\subsection{Family Views about Working Children}

The children's parents and guardians corroborated the children's view, with $88 \%$ saying that the reason the children were working was due to poverty and economic problems. A summary of the families' perceptions as to why the children are working is summarized below:

\section{Reason why Child is Working}

Poverty

Displacement

Death of parent

Learning a skill

Sickness/disability of parent

Unemployment of parent

Family problem (parents separated)

\section{No. of Replies}

265

41

32

29

13

9

Discussions with the parents revealed that 134 families (45\%) thought that the child's work was useful and would help prepare the child for a good future. These were primarily the families where the child was working in shops and factories (mechanical work, carpet shops, and shoe making). 166 families (55\%) thought that the child's work was not good for the child's future, but that the family's economic situation forced the child to work. Table 13 summarizes parents' opinions about their child's work:

Table 13: Parents' Opinions about their Child's Work

\section{Type of work}

Selling Water

Selling Food

Begging

Selling Small Items

Collecting Paper/fuel Items

Polishing Shoes

Cleaning Cars

Mechanical Work

Carpet Shop

Shoe Making
No. of parents' replies

Good Not Good , 
We asked family members what they thought would help improve the quality of their child's life. The following are their replies:

\section{What would Improve their Child's Life}

Training the child to learn a skill

Attending school

Financial assistance to the family

Employment for the child

Employment for the parent

Providing food/clothing/shelter

\section{No. of Replies}

\subsection{Community Views about Working Children}

"People are not thinking about the future of children or education. . . . . they only think day-to-day about how to get food, and how to survive." --Head of Education Dept.

"The reason there are working children is poverty. You must treat the root cause, not just the child. "-- Teacher at Community Forum discussion

In our discussions with community leaders, participants at community centres, and NGOs, the above views were reflected time and time again. The Heads of the Education and Literacy Departments have witnessed the disintegration of the government education system, with various changes of government and the majority of funds being channeled into the war effort. With a lack of materials and insufficient funds to pay teacher's salaries, it is not surprising that many parents choose to send their children to work, rather than to school. As expressed by one member of a community fora, "If children go to school, they will just waste their time".

Poverty was identified as the primary reason why children work. Many people thought that children should work to help support the family, and felt that skill development and learning a trade was more important than formal education.

Many of the participants in discussions shared similar views about the ways in which working children and their families could be assisted:

1. Set-up centres for skill development/vocational training for the children. The centres should combine skill training with education for the children. Suggestions for skill development were mechanics, electrical work, and carpentry for boys; and typing and computer skills, carpet making, weaving, and tailoring for girls. Several people suggested that skill development centres should be set-up in collaboration with the Education Department. 
2. Improve the economic conditions of the families. It was felt that unless the economic conditions of the family could be improved, children would be forced to continue working. Many people thought that income generation and credit/saving schemes for the families of working children should be developed. It was generally agreed that families should not be 'given aid', but should be assisted to develop more sustainable forms of income. Suggestions were to organise credit/savings programmes, and give people loans for looms, sewing machines, cows, or other family enterprises.

3. Work with the employers of child workers to improve conditions. Almost everyone we spoke to thought it was good for children to work in shops and factories to develop skills and help support their families. However, it was suggested that employers should be encouraged to reduce the working hours of children, and to allow time for literacy/education and recreation.

4. Establish a residential school for the children. Some people thought it would be good to establish a high-quality residential school for working children ("like the Turkish school"). 


\section{Section 6 Recommendations}

There are no easy solutions to the problems of working children. It is important to consider a variety of approaches, and coordinated action which will address the root causes, as well as improve conditions for the child.

From this Needs Assessment, it is clear that the main reason why children work in Mazar is the poor economic conditions of their families. In addition, there is a cultural acceptance that children should work to assist the family, and a belief by many families that skill development (learning a trade) is more important than formal education.

The following recommendations are offered as appropriate means of responding to the specific needs identified in the Needs Assessment of Working Children in Mazar-i-Sharif.

\section{Address the root cause (poverty) and improve family income and resources.}

Simply removing working children from the street or working place and providing them with support services or education does nothing to address the main reason why children work in Mazar-i-Sharif -- poverty. Any sustainable programme to assist working children must involve the family, with the aim to improve the family's economic situation. Specific suggestions are:

- Introduce credit and savings schemes for the families of working children.

- Develop family and community-based income generation programmes and micro-finance projects. This would initially require donor funding, although if linked to credit and saving schemes, families could repay loans once a sustainable income was achieved. Although many aid organisations tend to look for alternatives to traditional, gender-specific income generation, the most frequently cited suggestion was to give loans to families to purchase looms for carpet weaving.

\section{Increase opportunities for the child to acquire useful skills and expand his/her earning power.}

- Develop more facilities for children to learn technical skills which would guarantee the child's future earning power. Skills appropriate to Mazar would be mechanical work, carpentry, electronics, masonry, tailoring, carpet-making, and weaving. 
- Collaborate with employers of children to develop recognized apprenticeship schemes, rather than using 'trainees' as cheap labour. Help employers to develop training syllabuses, negotiate a fair wage for trainees, and give the child a certificate when she/he has successfully completed training. Provide the child with his/her own tools once they have completed training, or develop a savings scheme for trainees so that they can purchase their own tools.

- Channel working children into work which is more lucrative, develops skills, and is sustainable throughout the year (i.e. cleaning cars, mechanical work, or polishing shoes, rather than selling water.)

\section{Provide educational opportunities for working children}

Education should not be imposed on working children, but should be available and relevant to their lives. This means:

- Finding ways of taking appropriate learning to the workplace

- Ensuring that community literacy classes are available at times when working children can attend

- Using creative, participatory learning techniques

- Including health education and life skills in all educational programmes for working children

- Strengthening the capacity of the local education system, so that it is both attractive and affordable for working children.

\section{Protect Children from Exploitation and Ensure better working conditions}

This Needs Assessment did not identify specific types of work or situations in which children in Mazar are exposed to extremely harmful or hazardous working conditions. Children working in shops and factories worked normal working hours, were generally provided with food and time to rest, and were free to leave work if their family allowed. However, some children had to lift heavy objects and use tools that were sharp or heavy. Children working on the streets tended to work longer hours, often found carrying food and water to be heavy work, walked long distances, and were sometimes subject to threats and physical abuse from security guards. Steps which could be taken to improve the conditions for working children in Mazar-i-Sharif are:

- Help children working on the street to organise and form collectives, to protect them from abuse and exploitation (In Mazar, this could be initiated with children who clean cars and polish shoes.)

- Encourage employers to allow regular rest periods for child workers and protect children from work which is too heavy or dangerous

- Lobby for fair wages for child workers 


\section{Promote linkages and collaboration between existing programmes working with vulnerable groups in Mazar, and agencies involved with working children.}

Agencies and programmes in Mazar-i-Sharif which could collaborate in programmes which target working children and their families are:

- ACTED -- Provides coal for vulnerable families

- Departments of Education and Literacy

- ICRC -- Food for widows

- NBSD -- Planş to establish 2 centres for working children in Mazar

- SCF(UK) -- Health education and programme promoting Children's Rights

- SC(US) -- Promotes and facilitates savings and credit schemes, and has a programme for out-of-school children

- WFP -- Subsidized bread for poor families, food for work schemes

6. Advocacy and awareness raising with:

- Children -- on children's rights, access to education, health education, and improving working conditions

- Fanilies

-- to make parents aware of the specific needs and rights of children, to assist in the formation of parents groups or savings and credit groups, and to promote income generation

- Employers $\quad-$ - to improve the conditions of working children

- Communities .- to increase awareness about $\mathrm{CRC}$ and the special needs of working children

- Local government -- to promote legislation to promote the rights of children, and to strengthen the capacity of local government to provide services for children

\section{Involve children, their families, and local staff and community leaders in the planning and development of services for working children.}

All planning for project development should be based on the actual needs of the working children, and on the reality of their lives. The children and their families know best what they need, and we should continue to listen to them.

\section{Take time to plan responses that are sustainable.}

It is important not to launch into project proposals too quickly, before ensuring the capacity (human and financial resources) to sustain initiatives. It takes time and commitment to develop projects that really address poverty and have a positive impact on working children and their families. In the process of consulting with children and their families, expectations are raised and hopes kindled. Children's trust is often hard won, and it is important not to let them down. Programme planning must ensure that the impact on their lives will be positive and sustainable. 


\section{Save the Children's Position on Children and Work}

Save the Children"s position on children and work is based on the United Nations Convention on the Rights of the Child (CRC) and our experience, and that of our partner organisations, in a wide variety of cultures and contexts worldwide. The following articles are of particular relevance to children and work issues:

- $\quad$ Article 3, which states that all action taken involving or affecting children must be in their best interests

- Article 12, which states that children must be consulted on all action likely to affect them

- Article 32, which recognises children's right to be protected from economic exploitation and from performing any work that is hazardous or likely to interfere with their education or harm their health or development

- Article 27, which recognises the right of children to an adequate standard of living.

Save the Children recognises that children engage in a wide variety of forms of work, and that the conditions and nature of their work vary from occupations where children are able to develop responsibility and skills, and combine work with schooling, to conditions of extreme hazard and exploitation. The extent to which work is harmful or beneficial to children depends on a number of factors, including: the type of work; the hours they work; their age; their access to education: whether or not they are separated from their families for long periods and the degree to which they are exposed to specific hazards.

\section{Save the Children believes that:}

- the eradication of hazardous and exploitative forms of work, which jeopardise children's development is a priority for action.

- work which is not damaging to children's health or development, and allows children to develop skills, self-confidence and respect in their families and communities can be beneficial to their development. In such cases, or where earning income enables children to eat better or pay school-related expenses, work can be a positive experience for children. It is therefore essential to distinguish carefully between different kinds of work.

- to tackle the problems of exploitative and hazardous child labour in a sustainable manner, it is essential to address the root causes of poverty and social inequality as well as to improve the immediate situation of working children.

- the views of working children and their families must form an essential part of all action on child labour issues. They know their own immediate situations best, and it is their right to participate in planning initiatives which will affect their lives. 
Serial No:

Surveyor's Code:

Date:

\section{LOCATION OF CHILD}

1. District No:

2. Location of Working Place: a. On Street:

b. Shop: Type Location:

c. Factory: Type Location:

3. Location of Sleeping Place (Address):

\section{PROFILE OF CHILD}

4. Name:

5. Sex: Male Female

6. Age:

a. $<5$

b. $5-7$

c. $8-10$

d. 11-14

7. Ethnicity: a. Uzbek

b. Hazara

c. Tajik

d. Pashtun

e. Other

8. Have you ever been to school?

Yes

No

If yes: Are you still going to school?

Yes

No

Class:

If no: Why are you not going to school?
a. Economic problems
b. Displacement
c. I don't like school
d. Other: 
9. Why did you first start working?

10. How long have you been working?
a. $<3$ months
b. 4-6 months
c. 6 months -1 year
d. 1-2 years
e. $>2$ years

11. Where do you most often go for work?

12. Do you work:

a. In one place

b. Change locations

13. Do you work:

a. Alone

b. With others

If working with others, who are they?

14. Working Time: Usual starting time:

Usual finishing time:

Total number of hours worked per day:

15. How many days a week do you work?

$\begin{array}{lll}4 & 5 & 6\end{array}$ 7

16. What kind of work do you do?

$\underline{\text { In the Street }}$
a. Selling water
h. Mechanical work
b. Selling food
i. Carpet shop
c. Begging
j. Shoe Making
d. Selling small items (plastic, cigarettes)
k. Plastic bag making
e. Collecting paper/firewood/fuel items
f. Polishing shoes
g. Cleaning cars

Other

Other: 
17. How much money do you earn each day?

a. Afs

b. I do not earn money -- I give what I collect to my family

18. If you earn money, what do you do with it?
a. Give it to my family
b. Keep it for myself
c. Other:

19. Do you eat during working time?

Yes

No

What do you eat? a.

b.

How do you get the food?

20. Where do you sleep at night?
a. In his/her home
b. In relative's home
c. In friend's home
d. In the street
e. Other:

21. Do you have any free time?

Yes

No

If yes: When do you have free time? Morning

Afternoon

Evening

What do you do with your free time?

\section{CHILD'S NEEDS \& PROBLEMS}

22. Do you like the work you are doing?

Yes

No

If yes: What do you like most about working?

If no: What would you prefer to do?

23. What do you find most difficult about your work?

24. Do you have any problems while working? Yes

No If yes, what are your problems?

1. 2. 3. 
25. Have you ever been threatened or beaten while working?

If yes: By whom?

Why?

\section{SURVEYOR'S OBSERVATIONS ABOUT THE CHILD INTERVIEWED:}

Dirty

27. Does the child look malnourished? Yes

No

28. Is the child physically handicapped? Yes

No

If yes, give details:

\section{CHILD'S FAMILY BACKGROUND and LIVING SITUATION}

29. FATHER:

a. Alive and living with family

b. Alive, but not living with family (Where is he?

c. Dead

Father's Profession:

Father is presently: Employed

Unemployed

Father is educated: Yes

No

30. MOTHER:

a. Alive and living with family

b. Alive, but not living with family (Where is she?

c. Dead

Mother's Profession:

Mother is presently: Employed

Unemployed

Mother is educated: Yes

No 
Number of children in the family:

Male:

Female:

Ages of the children: From (lowest age) to (highest age)

32. Have any of your children died?

Yes

No

If yes, what was the cause?

a. Sickness/disease

b. Accident

c. Other

33. How many of your children are working? (Identify the child interviewed with a *)

No:

1

2

3

4

56

7

8

Sex:

Age:

Type of Work:

$(\mathrm{a}=$ On the street

$\mathrm{b}=$ In a shop

$c=$ In a factory)

34. Have you ever been a refugee?

Yes

No

Have you ever been displaced?

Yes

No

If yes, where were you living before coming to Mazar?

How long have you been living in Mazar?

35. How much is the average monthly income from all adults/children in the family? Afs

Who provides the main source of income? 
36. What do you think about your child doing this kind of work?
a.
b.
c.

37. What do you believe is the main reason that your child does this work?
a.
b.
c.

38. What does the family think would help improve the quality of their child's life?

a.

b.

c. 


\section{NAME LIST}

\section{CHILDREN WORKING IN THE STREETS OF MAZAR}

\section{Districyt}

\begin{tabular}{|c|c|c|c|c|c|}
\hline Serial No. & Name & M/F & Age & Type of work & School \\
\hline 1 & & & & & \\
\hline 2 & & & & & \\
\hline 3 & & & & & \\
\hline 4 & & & & & \\
\hline 5 & & & & & \\
\hline 6 & & & & & \\
\hline 7 & & & & & \\
\hline 8 & & & & & \\
\hline 9 & & & & & \\
\hline 10 & & & & & \\
\hline 11 & & & & & \\
\hline 12 & & & & & \\
\hline 13 & & & & & \\
\hline 14 & & & & & \\
\hline 15 & & & & & \\
\hline 16 & & & & & \\
\hline 17 & & & & & \\
\hline 18 & & & & & \\
\hline $19^{\circ}$ & & & & & \\
\hline 20 & & & & & \\
\hline 21 & & & & & \\
\hline 22 & & & & & \\
\hline 23 & & & & & \\
\hline 24 & & & & & \\
\hline 25 & & & & & \\
\hline 26 & & & & & \\
\hline 27 & & & & & \\
\hline 28 & & & & & \\
\hline 29 & & & & & \\
\hline 30 & & & & & \\
\hline 31 & & & & & \\
\hline 32 & & & & & \\
\hline 33 & & & & & \\
\hline 34 & & & & & \\
\hline 35 & & & & & \\
\hline
\end{tabular}

Code: Age $a=<5 \quad b=5-7 \quad c=8-10 \quad d=11-14$

Type of work: $a=$ Selling water $b=$ Selling food $c=$ Begging $d=$ Selling small items $\mathrm{e}=$ Collecting paper/fuel items $\mathrm{f}=$ Polishing shoes $\mathrm{g}=$ Cleaning cars $\mathrm{O}=\mathrm{O}$ ther 
IN MAZAR

DISTRICT

\begin{tabular}{|c|c|c|c|c|c|c|c|c|c|}
\hline $\begin{array}{c}\text { Serial } \\
\text { No }\end{array}$ & $\begin{array}{c}\text { Shop/Factory } \\
\text { Name }\end{array}$ & Location & $\begin{array}{c}\text { No Working } \\
\text { Children }\end{array}$ & $\begin{array}{l}\text { Name of } \\
\text { Child }\end{array}$ & $\mathbf{M} / \mathbf{F}$ & Age & $\begin{array}{c}\text { Relartive } \\
\text { Y/N }\end{array}$ & $\begin{array}{c}\text { School } \\
\text { Y/N }\end{array}$ & $\begin{array}{l}\text { Type of } \\
\text { Work }\end{array}$ \\
\hline \multicolumn{10}{|l|}{1} \\
\hline \multicolumn{10}{|l|}{2} \\
\hline \multicolumn{10}{|l|}{3} \\
\hline \multicolumn{10}{|l|}{4} \\
\hline \multicolumn{10}{|l|}{5} \\
\hline \multicolumn{10}{|l|}{6} \\
\hline \multicolumn{10}{|l|}{7} \\
\hline \multicolumn{10}{|l|}{8} \\
\hline \multicolumn{10}{|l|}{9} \\
\hline \multicolumn{10}{|l|}{10} \\
\hline \multicolumn{10}{|l|}{11} \\
\hline \multicolumn{10}{|l|}{12} \\
\hline \multicolumn{10}{|l|}{13} \\
\hline \multicolumn{10}{|l|}{14} \\
\hline \multicolumn{10}{|l|}{15} \\
\hline \multicolumn{10}{|l|}{16} \\
\hline \multicolumn{10}{|l|}{17} \\
\hline \multicolumn{10}{|l|}{18} \\
\hline \multicolumn{10}{|l|}{19} \\
\hline \multicolumn{10}{|l|}{20} \\
\hline \multicolumn{10}{|l|}{21} \\
\hline \multicolumn{10}{|l|}{22} \\
\hline \multicolumn{10}{|l|}{23} \\
\hline \multicolumn{10}{|l|}{24} \\
\hline 25 & & & & & & & & & \\
\hline
\end{tabular}


For further information, please contact

Save the Children (UK)

194-A, College Road

F-7/3, Islamabad, Pakistan

Telephone: $92-51-279214-5$

Facsimile : 92-51-279216

E-Mail: scfuk@infolink.net.pk

\section{Registered Office}

The Save the Children Fund

17 Grove Lane

London SE5 8RD 